\title{
LIST OF TABLES
}

1.1 Scottish migration to the West Indies, 1750-99

page 23

2.1 Plantation settlement in Tobago, 1770

3.1 The enslaved population on Hampden estate, Jamaica, 1771-80

4.1 Sugar prices at Glasgow, autumn 1777 97

6.1 Scots in the Windward Island legislatures, c. 1766-96 